\title{
Pengaruh Inflasi dan Pengangguran terhadap Penduduk Miskin di Sumatera Utara Tahun 2006-2020
}

\author{
Intan Permata Sari Br Sembiring ${ }^{1}$, Surtama Simanjuntak ${ }^{2}$, \\ Vini Alvionita Br Sitepu ${ }^{3}$ \\ Pendidikan Ekonomi Fakultas Ekonomi, Universitas Negeri Medan \\ Email: Intanpermatasaribrsembiring@gmail.com ${ }^{1}$, Surtamasimanjuntak@gmail.com², \\ vinialvionitasitepu@gmail.com ${ }^{3}$
}

\begin{abstract}
Abstrak
Penduduk Miskin adalah penduduk yang memiliki rata-rata pengeluaran perkapita perbulan dibawah garis kemiskinan. Masalah kemiskinan merupakan masalah yang kompleks dan multidimensi yang meliputi berbagai aspek dalam lini kehidupan manusia, tak terkecuali bagi pemerintah daerah di Sumatera Utara. Usaha untuk mengentaskan kemiskinan harus memperhatikan akar permasalahan kemiskinan itu sendiri. Indikator yang dipakai dalam penelitian ini adalah inflasi, pengangguran dan jumlah penduduk miskin. Penelitian ini bertujuan untuk menganalisis seberapa besar pengaruh Inflasi dan pengangguran terhadap penduduk miskin di Sumatera Utara periode 2006sampai dengan 2020 baik secara simultan maupun secara parsial. Jenis data yang digunakan dalam penelitian ini adalah data sekunder time series dari tahun 2006 sampai dengan 2020. Data yang digunakan yang digunakan ialah data yang diperoleh dari website resmi Badan Pusat Statistik (BPS) Sumatera Utara. Metode analisis yang digunakan dalam penelitian ini adalah analisis regresi linier berganda dengan software statistika SPSS. Hasil penelitian menunjukkan bahwa variabel inflasi berpengaruh positif dan tidak signifikan terhadap penduduk miskin di Provinsi Sumatera Utara dengan perolehan nilai sig 0.510>0,05; Secara parsial variabel pengangguran berpengaruh positif dan signifikan terhadap penduduk miskin di Provinsi Sumatera Utara dengan perolehan sig $0,000<0,05$; secara simultan variabel inflasi dan pengangguran berpengaruh signifikan terhadap penduduk miskin di Sumatera Utara pada tahun 2006- 2020
\end{abstract}

Kata Kunci: Pengangguran, Inflasi, Kemiskinan

\section{Pendahuluan}

Kemiskinan menurut World Bank tahun 2004, kemiskinan adalah karena kurangnya pendapatan dan aset (lack of income and assets) untuk memenuhi kebutuhan dasar seperti makanan, pakaian, perumahan dan tingkat kesehatan dan pendidikan yang dapat diterima (acceptable). Penduduk yang dapat dikatakan miskin adalah yang pendapatannya di bawah US\$ 1 per hari dan kemiskinan menengah untuk pendapatan di bawah US\$ 2 per hari. World Bank mendifinisikan kemiskinan itu sendiri adalah kondisi dimana seseorang tidak dapat menikmati segala macam pilihan dan kesempatan dalam pemenuhan kebutuhan dasarnya seperti tidak dapat memenuhi kesehatan, standar hidup layak, kebebasan, harga diri, dan rasa dihormati seperti orang lain.

Menurut Nasikun dalam Ginanjar Kartasasmita, kemiskinan adalah sebuah fenomena multifaset, multidimensional, dan terpadu. Hidup miskin bukan hanya berarti hidup di dalam kondisi kekurangan sandang, pangan, dan papan. Hidup dalam kemiskinan seringkali juga berarti akses yang rendah terhadap berbagai ragam sumber daya dan aset produktif yang sangat diperlukan untuk dapat memperoleh sarana pemenuhan kebutuhan-kebutuhan hidup yang paling dasar.

Menurut Quibria dalam Adit Agus Prasetyo mengatakan, Kemiskinan adalah suatu keadaan dimana seseorang berada dalam suatu kondisi yang serba kekurangan dalam memenuhi kebutuhan dasar, yakni kebutuhan pangan, pakaian dan tempat tinggal, dengan asumsi bahwa

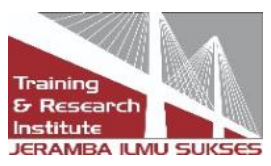


konsep kemiskinan ini bersifat time and societyspecific, artinya tidak berlaku universal karena konkret masing-masing masyarakat, kurun waktu memiliki ukuran yang berbeda tentang kemiskinan.

Badan Pusat Statistik mendefinisikan kemiskinan sebagai ketidakmampuan untuk memenuhi standar tertentu dari kebtuhan dasar, baik makanan maupun minuman.

Sedangkan menurut Bradly dan Schiller dalam Hendra Wahyudi dan Sismudjito "kemiskinan adalah ketidaksanggupan untuk mendapatkan barang-barang dan pelayanan yang memadai untuk memenuhi kebutuhan yang terbatas.

Kemiskinan adalah masalah lintas zaman, kenyataan ini kiranya menjadi latar belakang mengapa kemiskinan selalu menjadi masalah yang mendapatkan perhatian besar dan mengundang perdebatan. Namun terlepas dari semua kontroversi perdebatan yang ada tentang konsep kemiskinan, penuntasan penanggulan kemiskinan harus segera dilakukan dan setiap kebijakan yang dibuat harus memihak kepada rakyat miskin yang sangat membutuhkan perhatian dari semua pihak.

Kemiskinan terjadi karena rendahnya standart hidup orang-orang miskin yang berakibat pada buruknya angka harapan hidup dan pendidikan dapat menurunkan produktivitas ekonomi mereka. Seringkali masalah kemiskinan timbul bersama dengan masalah pengangguran. Kedua masalah ini erat kaitannya dengan tinggi rendahnya kualitas indeks pembangunan manusia.

Kemiskinan merupakan suatu fenomena yang kompleks dan sudah berakar pada berbagai sektor dan kondisi (Panji, 2016 dalam Aristina, 2017). Bagi masyarakat miskin, pemenuhan hak dasar atas pekerja yang layak ditentukan dari ketersediaan lapangan kerja yang dapat diakses, kemampuan untuk mempertahankan dan mengembangkan usaha, serta melindungi pekerja dari eksploitasi dan ketidakpastian kerja. Masyarakat miskin umumnya memiliki masalah dalam mendapatkan kesempatan kerja dan usaha, terbatasnya peluang mengembangkan usaha, perlindungan terhadap aset usaha, dan perbedaan upah serta lemahnya perlindungan kerja terutama bagi pekerja anak dan pekerja perempuan (Astrini, 2013 dalam Aristina, 2017). Upaya perluasan kesempatan kerja dilakukan untuk menciptakan lapangan kerja sehingga tingkat kemiskinan akan menurun (Ashcroft dan David, 2008 dalam Aristina, 2017).

Pengangguran dapat menyebabkan hilangnya atau berkurangnya keterampilan dan pengangguran menimbulkan ketidakstabilan ekonomi dan politik (Nanga, 2005 dalam Aristina, 2017). Pengangguran adalah masalah ketenagakerjaan yang sering dihadapi oleh setiap negara, khususnya negara berkembang seperti Indonesia. Menurut BPS pada sensus 2010, pengangguran didefinisikan sebagai orang yang masuk dalam angkatan kerja (15- 64) tahun yang sedang mencari pekerjaan dan belum mendapatkannya.

Tabel 1. Inflasi, Pengangguran, dan Penduduk Miskin

\begin{tabular}{|r|r|r|r|}
\hline Tahun & Inflasi & Pengangguran & $\begin{array}{c}\text { Penduduk } \\
\text { Miskin }\end{array}$ \\
\hline 2006 & 6.11 & 11.51 & 1979702 \\
\hline 2007 & 6.60 & 10.10 & 1770000 \\
\hline
\end{tabular}




\begin{tabular}{|r|r|r|r|}
\hline 2008 & 10.72 & 9.10 & 1630000 \\
\hline 2009 & 2.61 & 8.45 & 1500000 \\
\hline 2010 & 8.00 & 7.43 & 1490000 \\
\hline 2011 & 3.67 & 6.37 & 1436400 \\
\hline 2012 & 3.86 & 6.20 & 1400400 \\
\hline 2013 & 10.18 & 6.53 & 1416400 \\
\hline 2014 & 8.17 & 6.23 & 1360600 \\
\hline 2015 & 3.34 & 6.71 & 1508140 \\
\hline 2016 & 6.34 & 5.84 & 1452600 \\
\hline 2017 & 3.20 & 5.60 & 1326600 \\
\hline 2018 & 1.23 & 5.59 & 1324980 \\
\hline 2019 & 2.33 & 5.41 & 1282040 \\
\hline 2020 & 1.96 & 6.91 & 1283290 \\
\hline 206 & & & \\
\hline
\end{tabular}

Selanjutnya pada tahun 2006 jumlah penduduk miskin kembali mengalami peningkatan sebesar 197902 jiwa dan pada tahun 2007- 2012 penduduk miskin terus berkurang yaitu berturut- turut sebesar 209702 jiwa, 140000 jiwa, 130000 jiwa, 10000 jiwa, 53600 jiwa, 36000 jiwa. Tetapi, jumlah penduduk miskin kembali mengalami peningkatan sebesar 16000 jiwa pada tahun 2013. Kemudian ditahun 2014 turun lagi sebesar 55800 jiwa dan mengalami peningkatan sebesar 147540 jiwa di tahun 2015 yang kemudian menurun lagi pada tahun 2016-2019 yaitu masing sebesar 55540 jiwa, 126000 jiwa, 1620 jiwa, 42940 jiwa. Kemudian mengalami peningkatan ditahun 2020 sebesar 1250 jiwa.

Akhir-akhir ini, tepatnya saat pandemic COVID-19 melanda Indonesia, hal ini juga membawa dampak terhadap peningkatan tingkat kemiskinan di Sumatera Utara. Dikutip dari IDXchannel.com, jumlah penduduk miskin di sumatera utara bertambah 73 ribu orang Jumlah orang miskin di Sumatera Utara mencapai 1,36 juta jiwa. Angka yang tercatat pada September 2020 lalu, bertambahnya 73 ribu jiwa dibandingkan pencatatan sebelumnya pada Maret 2020. Angka kemiskinan Sumatera Utara mengalami peningkatan sebesar 0,39 poin yaitu dari 8,75\% pada Maret 2020 menjadi 9,14\% pada September 2020. Angka kemiskinan ini setara dengan 1,36 juta jiwa pada September 2020, atau bertambah sekitar 73 ribu jiwa dalam satu semester terakhir. Hal ini menunjukkan bahwa tingkat kemiskinan di Sumatera utara terus menerus menambah dan belum dapat ditanggulangi. Tingginya tingkat kemiskinan di Sumatera Utara ini dipengaruhi oleh beberapa faktor diantaranya: jumlah penduduk miskin, angka harapan hidup, pendidikan, tingkat pengangguran terbuka, inflasi, dll. Di sini peneliti memberikan batasan terhadap variabel $\mathrm{X}$, di mana variabel $\mathrm{X}$ yang dipakai oleh peneliti adalah inflasi dan tingkat pengangguran. 
Oleh sebab itu peneliti tertarik untuk meneliti bagaimana pengaruh inflasi dan tingkat pengangguran terhadap kemiskinan di Sumatera Utara. Adapun tujuan dari penelitian ini adalah: 1) untuk melihat seberapa besar pengaruh variable inflasi terhadap tingkat kemiskinan di Sumatera Utara, 2) untuk melihat seberapa besar pengaruh variable tingkat pengangguran terhadap tingkat kemiskinan di Sumatera Utara

\subsection{Rumusan Masalah}

1. Apakah ada pengaruh inflasi terhadap tingkat penduduk miskin di Sumatera Utara tahun 2006-2020?

2. Apakah ada pengaruh pengangguran terhadap tingkat penduduk miskin di Sumatera Utara tahun 2006-2020?

3. Apakah ada pengaruh inflasi dan pengangguran secara simultan terhadap penduduk miskin di Sumatera Utara tahun 2006-2020?

\subsection{Tujuan Penelitian}

1. Untuk mengetahui pengaruh inflasi terhadap tingkat penduduk miskin di Sumatera Utara tahun 2006-2020

2. Untuk mengetahui pengaruh pengangguran terhadap tingkat penduduk miskin di Sumatera Utara tahun 2006-2020

3. Untuk mengetahui pengaruh inflasi dan pengangguran secara simultan terhadap penduduk miskin di Sumatera Utara tahun 2006-2020

\subsection{Hubungan antara Variabel Bebas dan Variabel Terikat}

1. Hubungan antara Inflasi dengan Penduduk Miskin

Menurut penelitian Desrini Ningsih (2018), variabel inflasi berpengaruh positif dan signifikan terhadap kemiskinan di Indonesia. Hasil ini didukung dengan adanya teori bahwa inflasi akan meningkatkan biaya produksi yang menyebabkan kenaikan harga barang dan jasa. Kenaikan ini mengakibatkan daya beli masyarakat menurun yang menyebabkan peningkatan jumlah kemiskinan.

\section{Hubungan antara Pengangguran dengan Penduduk Miskin}

Hubungan yang positif antara kemiskinan dan pengangguran. Ketika tingkat pengangguran naik, maka tingkat kemiskinan juga naik dan ketika tingkat pengangguran menurun maka tingkat kemiskinan juga ikut turun. Sukirno (2004) menyatakan bahwa efek buruk dari pengangguran adalah mengurangi pendapatan masyarakat yang pada akhirnya mengurangi tingkat kemakmuran yang dicapai seseorang. Yang memiliki arti bahwa semakin tinggi tingkat pengangguran maka akan meningkatkan tingkat kemiskinan pula

\section{Landasan Teori}

\subsection{Inflasi}

Inflasi adalah suatu proses kenaikan harga-harga yang berlaku dalam suatu perekonomian. Sedangkan menurut Mandala Manurung (Kasim, 2021) pengertian Inflasi adalah kenaikan harga barang-barang yang bersifat umum dan terus-menerus. Menurut Adi Warmankarim secara umum Inflasi berarti kenaikan tingkat harga secara umum dari barang/komoditas atau jasa selama suatu periode waktu tertentu. Inflasi dapat dianggap sebagai fenomena moneter karena terjadinya penurunan nilai unit penghitungan moneter terhadap suatu komoditas. 
Inflasi adalah kecenderungan harga-harga barang naik secara terus menerus. Kenaikan hargaharga barang bersifat menyeluruh, jika hanya beberapa jenis barang saja maka tidak dikatakan inflasi kecuali jika kenaikan harga satu barang meluas dan berimbas pada kenaikan barang-barang lainnya (Boediono, 2008 dalam) (Khairil, 2018).

Inflasi yang tinggi menyebabkan menurunnya pendapatan riil masyarakat yang selama ini memiliki pendapatan tetap, juga dapat mengurangi nilai kekayaan masyarakat seperti uang simpanan di bank dan uang tunai yang dimiliki (Sukirno, 2013: 339) (dalam Khairil, 2018).

Dari beberapa pengertian Inflasi di atas maka dapat disimpulkan bahwa yang dimaksud dengan Inflasi adalah kenaikan harga-harga secara terus menerus dalam waktu tertentu. Kenaikan harga-harga yang berlaku dari satu waktu ke waktu lainnya tidak berlaku secara seragam. Kenaikan tersebut biasanya berlaku ke atas kebanyakan barang, tetapi tingkat kenaikannya berbeda.

\subsection{Pengangguran}

Mankiw (2006:154) (dalam Khairil, 2018) mengatakan bahwa pengangguran merupakan permasalahan makro ekonomi yang mempengaruhi masyarakat secara langsung dan menjadi masalah yang paling berat. Menurut Sukirno (2000: 474) (dalam Khairil, 2018). Pengangguran ialah masyarakat yang sudah masuk kedalam usia produktif atau usia kerja dan tergolong sebagai angkatan kerja namun tidak memiliki pekerjaan, kehilangan pekerjaan dan sedang mencari kerja.

Pengangguran menurut Sri Hermuningsih dikutip dari Deni Tisna, "pengangguran di definisikan sebagai ketidakmampuan angkatan kerja (labor forcé) untuk memperoleh pekerjaan sesuai yang mereka butuhkan dan mereka inginkan”.

Menurut BPS pengangguran adalah penduduk yang tidak bekerja tetapi sedang mencari pekerjaan atau sedang mempersiapkan suatu usaha baru atau penduduk yang tidak mencari pekerjaan karena merasa tidak mungkin mendapatkan pekerjaan, dan penduduk yang tidak aktif mencari pekerjaan dengan alasan sudah mempunyai pekerjaan tetapi belum mulai bekerja.

Pengangguran didefinisikan adalah seseorang yang tergolong dalam angkatan kerja dan secara aktif mencari pekerjaan pada suatu tingkat upah tertentu, tetapi tidak diperoleh pekerjaan yang diingikan (Sukirno, 2004).

Pengangguran dalam standar pengertian yang sudah ditentukan secara internasional yaitu seseorang yang sudah digolongkan dalam angkatan kerja yang secara aktif sedang mencari pekerjaan pada suatu tingkat upah tertentu, tetapi tidak dapat memperoleh pekerjaan yang diinginkannya. Menurut Sukirno (2010) (dalam Khairil, 2018), pengangguran biasanya dibedakan atas empat jenis berdasarkan keadaan yang menyebabkannya, antara lain:

1. Pengangguran friksional, yaitu para penganggur ini tidak ada pekerjaan bukan karena tidak dapat memperoleh kerja tetapi karena sedang mencari kerja lain yang lebih baik.

2. Pengangguran siklikal, yaitu penganguran yang melebihi pengangguran alamiah. Pada umumnya pengangguran ini terjadi sebagai akibat pengurangan dalam permintaan agregat. Penurunan permintaaan agregat mengakibatkan perusahaan mengurangi jumlah pekerja atau gulung tikar.

3. Pengangguran struktural, yaitu pengangguran yang disebabkan oleh adanya perubahan struktur kegiatan ekonomi. 
4. Pengangguran teknologi, yaitu pengangguran yang ditimbulkan oleh adanya penggantian tenaga manusia dengan mesin-mesin dan bahan kimia.

\subsection{Kemiskinan}

Supriatna (1997) (dalam Khairil, 2018) mendefinisikan kemiskinan sebagai kondisi serba terbatas pada suatu kelompok masyarakat yang terjadi bukan atas keinginan kelompok masyarakat itu sendiri. Masyarakat yang tergolong miskin ditandai dengan pendapatan yang rendah, kurang produktif, rendahnya tingkat kesehatan, rendahnya tingkat pendidikan dan rendahnya kualitas serta kesejahteraan hidup masyarakat.

Berdasarkan Undang-Undang No, 24 Tahun 2004, kemiskinan adalah kondisi sosial ekonomi seseorang atau sekelompok orang yang tidak terpenuhinya hak-hak dasarnya untuk mempertahankan dan mengembangkan kehidupan yang bermartabat. Kebutuhan dasar yang menjadi hak seseorang atau sekelompok orang meliputi kebutuhan pangan, kesehatan, pendidikan, pekerjaan, perumahan, air bersih, pertanahan, sumber daya alam, lingkungan hidup, rasa aman dari perlakuan atau ancaman tindak kekerasan, dan hak untuk berpartisipasi dalam penyelenggaraan kehidupan sosial dan politik. Laporan Bidang Kesejahteraan Rakyat yang dikeluarkan oleh Kementrian Bidang Kesejahteraan (Kesra) tahun 2004 menerangkan pula bahwa kondisi yang disebut miskin ini juga berlaku pada mereka yang bekerja akan tetapi pendapatannya tidak mencukupi untuk memenuhi kebutuhan pokok/dasar

\section{Metodologi}

Data Penelitian ini merupakan data sekunder perhitungan tahunan (yearly) dari tahun 20062020, jenis data yang digunakan dalam analisis ini yaitu data berskala (time series data). populasi yang digunakan adalah data-data yang ada di Sumatera Utara, meliputi inflasi, pengangguran, dan penduduk miskin tahun 2006-2020.

\subsection{Data}

Data yang digunakan untuk mencapai tujuan dalam penelitian ini sepenuhnya diperoleh melalui Badan Pusat Statistic Sumatera Utara dalam bentuk SUDA (Sumatera Utara Dalam Angka) serta bentuk-bentuk lain yang dikeluarkan oleh BPS Sumut periode 2006-2020 yang di akses melalui internet.

\subsection{Metode Analisis}

Dalam penelitian ini menggunakan analisis kuantitatif yaitu merupakan analisis yang menggunakan alat perhitungan statistik. Untuk mengetahui hubungan antar variabel penelitian ini menggunakan alat regresi linear berganda. Regresi linier berganda digunakan untuk menganalisis hubungan antar variabel terikat dengan variabel bebas. Dalam pengelolaan data digunakan software dalam komputer yaitu berupa spss 25. Secara sistematis dirumuskan sebagai berikut:

$$
Y=a+\beta_{1} X_{1}+\beta_{2} X_{2}
$$

Teknik Pengumpulan Data

Data yang digunakan untuk mencapai tujuan dalam penelitian ini sepenuhnya diperoleh melalui Badan Pusat Statistic Sumatera Utara dalam bentuk SUDA (Sumatera Utara Dalam Angka) serta bentuk-bentuk lain yang dikeluarkan oleh BPS Sumut tahun 2006-2020 yang di akses melalui internet. 


\section{Pembahasan}

Model Regresi Berganda

Tabel 2. Hasil Uji Regresi Berganda

\begin{tabular}{|l|l|c|l|c|}
\hline \multicolumn{5}{|c|}{ Coefficients $^{\text {a }}$} \\
\hline \multirow{2}{*}{ Model } & \multicolumn{2}{|c|}{$\begin{array}{c}\text { Unstandardized } \\
\text { Coefficients }\end{array}$} & $\begin{array}{c}\text { Standardized } \\
\text { Coefficien } \\
\text { ts }\end{array}$ \\
\cline { 2 - 5 } & \multicolumn{2}{|c|}{ B } & Std. Error & Beta \\
\hline \multirow{2}{*}{1} & (Constant) & $\mathbf{7 6 4 3 4 5 . 4 4 3}$ & 79966.925 & \\
\cline { 2 - 5 } & Inflasi & $\mathbf{4 6 5 8 . 3 4 8}$ & 6865.700 & .074 \\
\cline { 2 - 5 } & Pengangguran & $\mathbf{9 5 6 7 6 . 3 1 6}$ & 11511.580 & .907 \\
\hline \multicolumn{2}{|l|}{ a. Dependent Variable: PDD Miskin } \\
\hline
\end{tabular}

Berdasarkan Tabel diatas terdapat dua variabel bebas yaitu variabel inflasi dan pengangguran sehingga diperoleh persamaan regresi linier berganda sebagai berikut:

$$
\begin{gathered}
Y=a+\beta_{1} X_{1}+\beta_{2} X_{2} \\
Y=764345,443-4658.348 X_{1}+95676.316 X_{2}
\end{gathered}
$$

Persamaan regresi tersebut dapat dijelaskan sebagai berikut :

1. Nilai konstanta (a) sebesar 764345,443 , artinya jika inflasi $\left(X_{1}\right)$ dan pengangguran $\left(X_{2}\right)$ nilainya adalah 0 , maka nilai Pengangguran (Y) adalah 764345,443;

2. Nilai koefisien regresi variabel inflasi $\left(\mathrm{X}_{1}\right)$ sebesar 4658,348 , artinya jika variabel bebas lain nilainya tetap dan inflasi mengalami kenaikan 1 persen, penduduk miskin (Y) akan mengalami peningkatan sebesar 4658,348 jiwa. Koefisien bernilai positif artinya terjadi hubungan positif antara inflasi dengan penduduk miskin, semakin tinggi nilai inflasi maka semakin tinggi jumlah orang yang miskin;

3. Nilai koefisien regresi variabel pengangguran $\left(\mathrm{X}_{2}\right)$ sebesar 95676,316 , yang artinya bahwa setiap penambahan 1 persen nilai pengangguran maka akan menaikkan jumlah orang yang miskin sebanyak 95676,316 jiwa dengan asumsi bahwa variabel bebas lain tetap. Koefisien bernilai positif artinya terjadi hubungan positif antara pengangguran dengan penduduk miskin, semakin tinggi pengangguran maka semakin tinggi pula jumlah orang yang miskin.

Uji Asumsi Klasik

Uji Normalitas 
Tabel 3. Hasil Uji Normalitas

\begin{tabular}{|l|l|r|}
\hline \multicolumn{2}{|c|}{ One-Sample Kolmogorov-Smirnov Test } \\
\hline \multicolumn{2}{|c|}{} & $\begin{array}{c}\text { Unstandardized } \\
\text { Residual }\end{array}$ \\
\hline N & Mean & .0000000 \\
\hline Normal Parameters ${ }^{\text {a,b }}$ & Std. Deviation & .15 \\
\hline Most Extreme Differences & Absolute & .089 \\
\cline { 2 - 4 } & Positive & -.103 \\
\cline { 2 - 4 } & Negative & .103 \\
\hline Test Statistic & & $\mathbf{. 2 0 0}$ c,d \\
\hline Asymp. Sig. (2-tailed) & & \\
\hline a. Test distribution is Normal. & & \\
\hline b. Calculated from data. & & \\
\hline c. Lilliefors Significance Correction. & & \\
\hline d. This is a lower bound of the true significance. & \\
\hline
\end{tabular}

Berdasarkan tabel One-Sample Kolmogorov-Smirnov Test di atas diketahui bahwa nilai Sig $>$ 0,05, maka dapat disimpulkan bahwa tidak terjadi pelanggaran uji normalitas dalam penelitian ini.

Uji Multikolinearitas

Tabel 4. Hasil Uji Multikolinearitas

\begin{tabular}{|c|c|c|c|c|c|}
\hline \multicolumn{6}{|c|}{ Model Summary } \\
\hline $\begin{array}{c}\text { Mode } \\
1\end{array}$ & $\mathrm{R}$ & R Square & $\begin{array}{c}\text { Adjusted R } \\
\text { Square }\end{array}$ & $\begin{array}{c}\text { Std. Error of } \\
\text { the } \\
\text { Estimate }\end{array}$ & $\begin{array}{l}\text { Durbin- } \\
\text { Watson }\end{array}$ \\
\hline 1 & $.936^{\mathrm{a}}$ & .875 & .854 & 72837.21572 & 1.042 \\
\hline
\end{tabular}


b. Dependent Variable: PDD Miskin

Berdasarkan hasil estimasi diperoleh nilai Durbin Watson (DW) hitung sebesar 1,042. Oleh karena $\mathrm{n}=15$ (banyak tahun) dan $\mathrm{k}=2$ (jumlah variabel bebas) dan membandingkan dengan tabel DW, maka diperoleh nilai dL sebesar 0,9455 dan du sebesar 1,5432. Artinya nilai Dw berada diantara nilai Dl dan Du sehingga dapat disimpulkan bahwa data berada pada tahap tidak dapat diputuskan. Sehingga perlu diuji lanjut yaitu menggunakan Runs Test.

Tabel 5. Hasil Runs Test

\begin{tabular}{|l|r|}
\hline \multicolumn{2}{|c|}{ Runs Test } \\
\hline & $\begin{array}{r}\text { Unstandardiz } \\
\text { ed Residual }\end{array}$ \\
\hline Test Value ${ }^{\mathrm{a}}$ & 8578.67430 \\
\hline Cases < Test Value & 7 \\
\hline Cases >= Test Value & 15 \\
\hline Total Cases & 6 \\
\hline Number of Runs & -1.059 \\
\hline Z Sig. (2- & $\mathbf{2 9 0}$ \\
\hline $\begin{array}{l}\text { Asymp. } \\
\text { tailed })\end{array}$ & \\
\hline a. Median & \\
\hline
\end{tabular}

Berdasarkan tabel Runs Test di atas diperoleh nilai sig. sebasar 0,290 > 0,05 artinya bahwa tidak ada masalah autokorelasi pada data penelitian ini.

Uji Multikolinearitas

Tabel 6. Hasil Uji Multikolinearitas

\begin{tabular}{|c|c|c|c|c|c|c|}
\hline \multicolumn{7}{|c|}{ Coefficients $^{\mathrm{a}}$} \\
\hline \multirow{2}{*}{\multicolumn{2}{|c|}{ Model }} & \multicolumn{2}{|c|}{$\begin{array}{c}\text { Unstandardized } \\
\text { Coefficients }\end{array}$} & \multirow{3}{*}{\begin{tabular}{|c}
$\begin{array}{c}\text { Standardized } \\
\text { Coefficien } \\
\text { ts }\end{array}$ \\
Beta
\end{tabular}} & \multicolumn{2}{|c|}{$\begin{array}{r}\text { Collinearity } \\
\text { Statistics }\end{array}$} \\
\hline & & B & Std. Error & & Tolerance & VIF \\
\hline \multirow[t]{2}{*}{1} & (Constant) & 764345.443 & 79966.925 & & & \\
\hline & Inflasi & 4658.348 & 6865.700 & .074 & .874 & 1.145 \\
\hline
\end{tabular}




\begin{tabular}{|l|l|l|l|l|l|}
\hline Pengangguran & 95676.316 & 11511.580 & .907 & .874 & $\mathbf{1 . 1 4 5}$ \\
\hline
\end{tabular}

a. Dependent Variable: PDD Miskin

Berdasarkan Tabel diatas dengan kriteria bahwa jika nilai VIF $<10$ artinya di dalam model tidak terdapat multikolinearitas, maka dapat disimpulkan bahwa tidak terjadi permasalahan multikolinearity dalam data penelitian ini karena nilai VIF $<10$.

Uji Regresi

Tabel 7. Hasil Uji Regresi

\section{R-squared}

\begin{tabular}{|c|c|c|c|c|}
\hline \multicolumn{5}{|c|}{ Model Summary ${ }^{b}$} \\
\hline $\begin{array}{c}\text { Mode } \\
1\end{array}$ & $\mathrm{R}$ & R Square & $\begin{array}{c}\text { Adjusted R } \\
\text { Square }\end{array}$ & $\begin{array}{c}\text { Std. Error of } \\
\text { the } \\
\text { Estimate }\end{array}$ \\
\hline 1 & $.936^{\mathrm{a}}$ & .875 & .854 & $\begin{array}{r}72837.2157 \\
2\end{array}$ \\
\hline \multicolumn{5}{|c|}{ a. Predictors: (Constant), Pengangguran, Inflasi } \\
\hline \multicolumn{5}{|c|}{ b. Dependent Variable: PDD Miskin } \\
\hline
\end{tabular}

Berdasarkan tabel diatas diperoleh nilai R-squared sebesar 0,875 yang artinya bahwa variabel inflasi dan pengangguran mampu mempengaruhi penduduk miskin di provinsi Sumatera Utara pada tahun 2006-2020 sebesar 87,5\% dan sisanya sebesar 12,5\% dipengaruhi oleh faktor lain yang tidak diteliti pada penelitian ini contohnya besar upah, pendidikan, pertumbuhan ekonomi dan jumlah penduduk di suatu wilayah

1. Uji t

Tabel 8. Hasil Uji t

\begin{tabular}{|c|c|c|c|c|c|c|}
\hline \multicolumn{7}{|c|}{ Coefficients $^{\mathbf{a}}$} \\
\hline \multirow{2}{*}{\multicolumn{2}{|c|}{ Model }} & \multicolumn{2}{|c|}{$\begin{array}{c}\text { Unstandardized } \\
\text { Coefficients }\end{array}$} & \multirow{2}{*}{$\begin{array}{c}\begin{array}{c}\text { Standardized } \\
\text { Coefficien } \\
\text { ts }\end{array} \\
\text { Beta }\end{array}$} & \multirow[t]{2}{*}{$\mathrm{t}$} & \multirow[t]{2}{*}{ Sig. } \\
\hline & & B & Std. Error & & & \\
\hline \multirow[t]{3}{*}{1} & (Constant) & 764345.443 & 79966.925 & & 9.558 & .000 \\
\hline & Inflasi & 4658.348 & 6865.700 & .074 & .678 & .510 \\
\hline & Pengangguran & 95676.316 & 11511.580 & .907 & 8.311 & .000 \\
\hline
\end{tabular}


a. Dependent Variable: PDD Miskin

Berdasarkan Tabel diatas, dapat diperoleh kesimpulan sebagai berikut:

a. Inflasi dan Penduduk Miskin

Secara parsial variabel inflasi berpengaruh positif dan tidak signifikan terhadap penduduk miskin di Provinsi Sumatera Utara dengan perolehan nilai sig $0.510>0,05$ yang artinya inflasi tidak signifikan terhadap kemiskinan pada taraf 5\%.

Penelitian ini sesuai dengan penelitian yang dilakukan oleh Khairil Ihsan dan Ikhsan, S.E, M.A. (2018), dengan judul "Analisis Pengaruh UMP, Inflasi Dan Pengangguran Terhadap Kemiskinan Di Provinsi Aceh". Hasil dari pendekatan model random menunjukkan bahwa upah minimum berpengaruh positif dan signifikan terhadap kemiskinan, inflasi berpengaruh positif namun tidak signifikan terhadap kemiskinan.

\section{b. Pengangguran dan Penduduk Miskin}

Secara parsial variabel pengangguran berpengaruh positif dan signifikan terhadap penduduk miskin di Provinsi Sumatera Utara dengan perolehan sig 0,000 $<0,05$ yang artinya pengangguran signifikan terhadap kemiskinan pada taraf 5\%.

Penelitian ini sesuai dengan penelitian yang dilakukan oleh Listyaningrum Kusuma Wardani (2013) dengan judul "Pengaruh Pengangguran, Pengeluaran Pemerintah dan jumlah penduduk terhadap Kemiskinan di Provinsi Jawa Tengah tahun 2006-2010". Hasil penelitian menunjukan Ada pengaruh dan signifikan antara pengangguran terhadap kemiskinan $\mathrm{Kab} /$ Kota di Jawa Tengah tahun 2006-2010.

Penelitian oleh Eka Agustina (2018), dengan judul "Pengaruh jumlah penduduk, tingkat pengangguran dan tingkat pendidikan terhadap tingkat kemiskinan di provinsi Aceh". Hasil penelitian menunjukan Dari uji simultan (uji F) dapat disimpulkan bahwa secara bersamasama variabel jumlah penduduk, tingkat pengangguran dan tingkat pendidikan berpengaruh signifikan terhadap kemiskinan di Provinsi Aceh. Secara parsial tingkat pengangguran berpengaruh positif dan signifikan terhadap kemiskinan di provinsi Aceh.

\section{Uji f}

Tabel 9. Hasil Uji F

\begin{tabular}{|c|c|c|c|c|c|c|}
\hline \multicolumn{7}{|c|}{ ANOVA $^{a}$} \\
\hline \multicolumn{2}{|c|}{ Model } & \multirow{2}{*}{$\begin{array}{c}\begin{array}{c}\text { Sum of } \\
\text { Squares }\end{array} \\
44656516343 \\
8.849\end{array}$} & \multirow{2}{*}{$\begin{array}{l}\text { df } \\
2\end{array}$} & \multirow{2}{*}{$\begin{array}{r}\text { Mean Square } \\
22328258171 \\
9.424\end{array}$} & \multirow{2}{*}{$\begin{array}{c}\mathrm{F} \\
42.087\end{array}$} & \multirow{2}{*}{$\begin{array}{l}\text { Sig. } \\
.000^{\mathrm{b}}\end{array}$} \\
\hline 1 & Regression & & & & & \\
\hline & Residual & $\begin{array}{r}63663119924 \\
.885\end{array}$ & 12 & $\begin{array}{r}5305259993 . \\
740\end{array}$ & & \\
\hline & Total & $\begin{array}{r}51022828336 \\
3.733\end{array}$ & 14 & & & \\
\hline
\end{tabular}


a. Dependent Variable: PDD Miskin

b. Predictors: (Constant), Pengangguran, Inflasi

Berdasarkan hasil olah data diperoleh nilai Prob (F-statistic) seperti pada diatas yaitu sebesar $0.000<0,05$ yang artinya secara simultan variabel inflasi dan pengangguran berpengaruh signifikan terhadap penduduk miskin di Sumatera Utara pada tahun 2006-2020.

Hal ini sesuai dengan hasil penelitian Norristyo Cokrowidagdo tentang "Pengaruh tingkat inflasi dan pengangguran terhadap tingkat kemiskinan di Propinsi Jawa Timur" yang mengatakan bahwa terdapat pengaruh signifikan secara bersama- sama (simultan) antar variabel independen terhadap variabel dependen.

\section{Kesimpulan}

Dari hasil penelitian diatas penulis menarik kesimpulan bahwa:

1. Secara parsial variabel inflasi berpengaruh positif dan tidak signifikan terhadap penduduk miskin di Provinsi Sumatera Utara dengan perolehan nilai sig 0.510>0,05 yang artinya inflasi tidak signifikan terhadap kemiskinan pada taraf 5\%.

2. Secara parsial variabel pengangguran berpengaruh positif dan signifikan terhadap penduduk miskin di Provinsi Sumatera Utara dengan perolehan sig 0,000 < 0,05 yang artinya pengangguran signifikan terhadap kemiskinan pada taraf $5 \%$.

3. Secara simultan variabel inflasi dan pengangguran berpengaruh signifikan terhadap penduduk miskin di Sumatera Utara pada tahun 2006-2020 dengan nilai nilai Prob (Fstatistic) seperti pada diatas yaitu sebesar $0.000<0,05$.

\section{Saran}

Berdasarkan penelitian yang telah dilakukan maka kami memberikan sedikit saran, sebagai berikut:

1. Pemerintah harus meningkatkan SDM dan membuka lapangan pekerjaan untuk mengatasi pengangguran dan menurunkan jumlah penduduk miskin di Sumatera Utara

2. Pemerintah harus mampu untuk menjaga kestabilan inflasi;

3. Untuk peneliti yang akan datang supaya dapat menambah variabel penelitiannya.

\section{Daftar Pustaka}

Aristina, ita \& dkk. (2017). Pengaruh Tingkat Pendidikan, Pengangguran, Dan Pertumbuhan Ekonomi Terhadap Kemiskinan Di Provinsi Bali. Jurnal ekonomi pembangunan. Vol. 6, No. $5 . \quad$ ISSN: http://erepo.unud.ac.id/id/eprint/15695/1/67bbde3e33901396f12a48de9d8129f8.pdf

Cokrowidagdo. (2017). Pengaruh tingkat inflasi dan pengangguran terhadap tingkat kemiskinan di Propinsi Jawa Timur.https://jimfeb.ub.ac.id/index.php/jimfeb/article/view/4105

Eka Agustina, dkk. (2018). Pengaruh jumlah penduduk, tingkat pengangguran dan tingkat pendidikan terhadap tingkat kemiskinan di provinsi Aceh. Jurnal Perspektif Ekonomi
Darussalam.
Vol.
4, No.
2.
ISSN.
2502-6976. 
http://jurnal.unsyiah.ac.id/JPED/article/view/13022

Listyaningrum Kusuma Wardani. (2013). Pengaruh Pengangguran, Pengeluaran Pemerintah dan jumlah penduduk terhadap Kemiskinan di Provinsi Jawa Tengah tahun 20062010. Skripsi. http://lib.unnes.ac.id/id/eprint/18211.

Khairil Ihsan \& Ikhsan, S.E, M.A. (2018). Analisis Pengaruh Ump, Inflasi Dan Pengangguran Terhadap Kemiskinan Di Provinsi Aceh. Jurnal Ilmiah Mahasiswa. Vol. 3, No. 3. ISSN.2549-8363. analisis Pengaruh Ump, Inflasi Dan Pengangguran Terhadap Kemiskinan Di Provinsi Aceh | Ihsan | Jurnal Ilmiah Mahasiswa Ekonomi Pembangunan (unsyiah.ac.id)

Kasim, Rahmat dkk .(2021). Analisis Pengaruh Inflasi, Pengangguran Dan Belanja Pemerintah Terhadap Kemiskinan Di Kota Manado. Jurnal EMBA. Vol. 9, No. 1. ISSN 2303-1174. https://ejournal.unsrat.ac.id/index.php/emba/article/viewFile/32645/30878

Ningsih, Desrini dan Puti Andiny. (2018). Analisis Pengaruh Inflasi dan Pertumbuhan Ekonomi Terhadap Kemiskinan di Indonesia. JURNAL SAMUDRA EKONOMIKA, VOL. 2 , NO. https://ejurnalunsam.id/index.php/jse/article/download/777/620\#: :text=Jika\%20infla si\%20meningkat $\% 20$ maka $\% 20$ kemiskinan,kenaikan $\% 20$ harga $\% 20$ barang $\% 20$ dan $\% 2$ 0jasa. 